\title{
Organic and conventional management in a Parda Alpina dairy goat production system in northeastern Brazil
}

\section{Manejo orgânico e convencional do sistema de produção de cabras leiteiras Parda Alpina no Nordeste do Brasil}

\author{
Wilma Emanuela da Silva'; João Paulo Guimarães Soares²; \\ Jenevaldo Barbosa da Silva ${ }^{3 *}$; Débora Andréa Evangelista Façanha ${ }^{4}$; \\ Luiz Januário Magalhães Aroeira ${ }^{5}$; Juaci Vitória Malaquias ${ }^{6}$; Jean Berg Alves da \\ Silva ${ }^{4}$; Ana Carla Diógenes Suassuna Bezerra ${ }^{4}$; Maria Rociene Abrantes ${ }^{1}$
}

\begin{abstract}
In this study, we compared organic and conventional management in a dairy goat production system in Angicos, Rio Grande do Norte, Northeastern Brazil. Twenty-six Parda Alpina dairy goats were used: 13 in organic management $(\mathrm{OM})$ and 13 in conventional management $(\mathrm{CM})$. The experimental design was completely randomized with two treatments and 13 repetitions. OM practices included estrus synchronization with the "male effect," an herbal-based treatment against endoparasitoses (an extract of lemon [Citrus limonum] and garlic [Allium sativum]) and the control of mastitis using the Embrapa Kit for manual milking with a rosemary pepper (Lippia sidoides) tincture. CM animals received synthetic hormones (Promone ${ }^{\circledR}$, Prolise ${ }^{\circledR}$, and Novormon ${ }^{\circledR}$ ) for synchronization of estrus, ivermectin for endoparasitoses, and iodized alcohol for mastitis prevention aided by the Embrapa Kit for manual milking. No significant differences were observed between the management types in the pregnancy rate, FEC, FAMACHA® (Faffa Malan Chart) scores, physico-chemical composition of the milk, or somatic cell count (SCC). Both OM and MC had pregnancy rates of $61.54 \%$. The mean values of the egg counts observed in the $\mathrm{OM}$ and $\mathrm{CM}$ were 24 and 35 eggs g$^{-1}$, respectively. The FAMACHAC scores were 1 or 2 and 2, 3, or 4 in $\mathrm{OM}$ and $\mathrm{CM}$, respectively. The goats had average weights in $\mathrm{OM}$ of $48.53 \mathrm{~kg}$ and in $\mathrm{CM}$ of $55.92 \mathrm{~kg}$. Milk production, fat, protein, lactose, total solids, and nonfat solids in OM $(0.971$ $\mathrm{kg} /$ day, $2,210,2,322,3,306,7,866,5,566$, respectively) were slightly higher than those in CM $(0.946$ $\mathrm{kg} /$ day, $1,812,1,812,2.868,6.74,4.928) . \mathrm{OM}(904,860 \mathrm{cells} / \mathrm{mL})$ and $\mathrm{CM}(1.02052$ million cells $/ \mathrm{mL})$ SCC values were similar, with the OM within the acceptable range for milk goats. Organic management was equivalent to conventional management for weight gain, maintenance of animal health standards, reproductive and sanitary control, and milk quantity and quality, and is technically suitable for a dairy goat production system in semiarid conditions.
\end{abstract}

Key words: Agroecology, male effect, internal parasites, herbal medicine, mastitis

1 Discentes, Programa de Pós-Graduação em Ciência Animal. PPCA, Universidade Federal Rural do Semi-Árido, UFERSA, Mossoró, RN, Brasil.E-mail: wilma_manu1@hotmail.com; rocienevet3@hotmail.com

2 Pesquisador, Embrapa Cerrados, Empresa Brasileira de Pesquisa Agropecuária, Embrapa, Planaltina, DF, Brasil. E-mail: jp.soares@embrapa.br

3 Discente, Dept ${ }^{\circ}$ de Patologia Veterinária, Faculdade de Ciências Agrárias e Veterinárias, Universidade Estadual Paulista, FCAV/ UNESP, Jaboticabal, SP, Brasil. E-mail: jenevaldo@hotmail.com

4 Profs., UFERSA, Mossoró, RN, Brasil. E-mail: debora_ufersa@hotmail.com; jeanberg@ufersa.edu.br; acdsuassuna@hotmail. com

5 Pesquisador, Embrapa Gado de Leite, Empresa Brasileira de Pesquisa Agropecuária, Juiz de Fora, MG, Brasil. E-mail: ljmaroeira@yahoo.com.br

6 Analista, Embrapa Cerrados, Embrapa, Planaltina, DF, Brasil. E-mail: juaci.malaquias@embrapa.br

* Author for correspondence 


\section{Resumo}

Objetivou-se neste trabalho comparar o manejo orgânico e convencional de um sistema de produção de caprinos leiteiros em Angicos, Rio Grande do Norte, Nordeste do Brasil. Foram utilizadas 26 cabras da Raça Parda Alpina em lactação, sendo 13 em manejo orgânico (MO) e 13 em manejo convencional (MC). O delineamento experimental foi o inteiramente casualizado, com dois tratamentos e 13 repetições. Os animais do MO foram submetidos à sincronização de estro com efeito macho, tratamento à base de fitoterápicos contra endoparasitoses (Extrato de limão (Citrus Limonium) e alho (Allium sativum), e no controle de mastite usando o Kit Embrapa de ordenha manual à base de alecrim pimenta (Lippia sidoides). No MC os animais receberam hormônios sintéticos (Promone-e ${ }^{\circledR}$, Prólise ${ }^{\circledR}$ e Novormon ${ }^{\circledR}$ ) para a sincronização do estro, Ivermectina para endoparasitoses e álcool iodado para prevenção de mastite auxiliado pelo Kit Embrapa de ordenha manual. Não houve diferença significativa para os resultados de porcentagem de prenhezes, OPG, escores do FAMACHAC, composição físico-química do leite e Contagem de Células Somáticas (CCS) nos dois tipos de manejo. No MO e MC as cabras apresentaram médias de percentagem de prenhezes positiva de $61,54 \%$ em ambos os sistemas. Os valores médios da contagem de ovos observados nos MO e MC foram de 24 e 35 de OPG, respectivamente. Pelo método FAMACHAC observou-se escores de 1 e 2; 2, 3 e 4 no $\mathrm{MO}$ e MC respectivamente. As cabras apresentaram pesos médios no $\mathrm{MO}(48,53 \mathrm{Kg})$ e $\mathrm{MC}(55,92 \mathrm{Kg})$. A produção de leite, gordura, proteína, lactose, extrato seco total e extrato seco desengordurado no $\mathrm{MO}(0,971 \mathrm{~kg} / \mathrm{dia} ; 2,210 ; 2,322 ; 3,306$; $7,866 ; 5,566)$ foram ligeiramente superiores aos valores do MC $(0,946 \mathrm{~kg} / \mathrm{dia} 1,812 ; 1,812 ; 2,868 ; 6,74$; 4,928). Para a CCS o MO $(904.860 \mathrm{cel} / \mathrm{mL})$ e MC $(1.020 .520 \mathrm{cel} / \mathrm{mL})$ apresentaram valores próximos, estando o MO dentro dos valores aceitáveis para leite de cabra. $\mathrm{O}$ manejo orgânico foi equivalente ao manejo convencional quanto ao ganho de peso, manutenção dos padrões de saúde dos animais, controle reprodutivo e sanitário e quanto à quantidade e qualidade do leite, mostrando-se tecnicamente adequado ao sistema de produção de cabras leiteiras nas condições do semiárido.

Palavras-chave: Agroecologia, efeito macho, endoparasitas, fitoterápicos e mastite

\section{Introduction}

In Brazilian semiarid regions, it is possible to obtain organic products from dairy goats and sheep because of factors such as the low use of technology (e.g., fertilizers and drugs) by the producer. Therefore, the production of milk and meat is already very close to that type of production. This extensive system is the most widely adopted in this region, with several characteristics that are similar to the recommended model of organic production. However, it still requires methodological adjustments and logistic support from the institutions responsible for organizing production and public policies that are already being developed and standardized in order to guide the producers (BRASIL, 2003, 2012).

Currently, there is an increasing demand for organic food, which is therefore becoming an important market segment. This has prompted producers all over the world, especially in countries that export agricultural products, to adopt technologies that are sustainable for the primary resources and the preservation and increase of biodiversity, in order to satisfy the consumers of this market segment (D'ALMEIDA, 2005). In Brazil, the demand for organic products has grown approximately $30 \%$ a year (FIGUEIREDO; SOARES, 2012), which indicates that consumers are interested in milk from animals raised in systems that promote their well-being and that are sustainable and environmentally appropriate. For the consumer, the price of organic bovine milk is up to three times that of the conventional product, especially in the Southeastern Region, which has higher purchasing power (AROEIRA; FERNANDES, 2001).

Even though there is a great potential for the production of organic animal products in Brazil, such production is still incipient in the country. The annual production of organic cow milk, approximately 6.8 million liters in 2010, is less than $0.02 \%$ of the total (SOARES et al., 2011). In 
the case of goat milk, there is only one initiative in the Northeastern Region, although there are no official data. Different factors can explain this small production, such as the scarceness of research on feeding, breed patterns, and the hygienic care of the herds, especially for infection by gastrointestinal helminthes (HÖGLUND et al., 2001; SILVA; FAGUNDES, 2011).

In this context, it is very pertinent to study the adoption of goatherd management practices that are more economical and efficiently handle goat reproduction and the control of endoparasitoses and mastitis. Organic management in terms of hygiene and reproduction is extremely important in the production of goat milk, since, apart from being a natural way of handling that takes into account the physiology of the animals, it reduces the costs from drugs and improves the quality of the products, which will be ecologically healthier, therefore, reducing the amount of residues in the milk.

The present study aimed to validate the hygienic and reproductive organic management of Parda Alpina dairy goat production systems in the municipality of Angicos, Rio Grande do Norte, Brazil.

\section{Material and Methods}

The experiment was carried out in the commercial farm Hebron I, located in the municipality of Angicos in the semiarid region of the State of Rio Grande do Norte, Brazil (5 $5^{\circ} 39^{\prime} 56^{\prime \prime} \mathrm{S}$ latitude and $36^{\circ} 36^{\prime} 04^{\prime \prime} \mathrm{W}$ longitude). The region has a mild climate, with temperatures ranging from $25^{\circ} \mathrm{C}$ to $33^{\circ} \mathrm{C}$, and an average temperature of $29^{\circ} \mathrm{C}$, according to the agricultural census of 2013 (IBGE, 2013). Precipitation from January 2012 to February 2013 totaled $288.2 \mathrm{~mm}$, with $193.5,19,16.5$, and $12.5 \mathrm{~mm}$ in the months of February, March, April, and May, respectively, and $0.0 \mathrm{~mm}$ between June and December 2012. In January and February 2013, the precipitation was 4.0 and $3.3 \mathrm{~mm}$, respectively (PREFEITURA MUNICIPAL DE ANGICOS,
2013).

Twenty-six adult female Parda Alpina goats of varying ages, each identified by numbered neck collars, were used in the study. They were weighed at the beginning and every 15 days until the end of the experiment, and confirmed as not pregnant via ultrasound examination. The animals were divided into two groups of 13 goats. One group was subjected to organic management (OM), and the other to conventional management $(\mathrm{CM})$.

The feeding system for both groups was carried out according to the regulations for organic management proposed by Soares et al. (2010); the animals received approximately $200 \mathrm{~g}$ of concentrate in the trough and burnt Xiquexique (Pilosocereus gounellei) in order to improve their nutrition, as well as litter from regional plants of the caatinga, and native pasture.

\section{Organic management}

The experiment was carried out from May to February 2013, including the pregnancy and lactation periods. In the reproductive protocol, the goats belonging to the OM group were initially induced to estrus, with practices and processes allowed in organic production (SOARES et al., 2010). The male effect was used for estrus synchronization and phytotherapic medicine for milking hygiene and wounds in general. The female goats were kept away from the males before being put in their presence, and upon showing behavioral signs of estrus, they were subjected to natural, controlled copulation.

For the control of endoparasites, evaluations were perfumed by assessing the conjunctive color by comparison with an illustrative card associated with the FAMACHAC technique in order to determine the anemia level of the animals (WYK; BATH, 2002). Based on this comparison, only the animals that presented a mucosa coloration corresponding to Level 4 or 5 were treated. For seven consecutive 
days, they were orally given approximately $20 \mathrm{~mL}$ of a solution containing garlic (Allium sativum), lemon (Citrus limonum), and salt, in accordance with Maia et al. (2009). This treatment was associated with the FAMACHAC, so that only the animals presenting clinical anemia were dewormed.

For the performance of hygiene procedures during milking, we used the Embrapa Kit for manual milking for dairy goats (CHAPAVAL et al., 2009) and a glycerin solution composed of $15 \%$ rosemary-pepper (Lippia sidoides) tincture for postdipping (teat asepsis after milking), twice a day (in the morning and in the afternoon). In this system, milking was manual, and the strip cup test was used for mastitis diagnosis during the first three months of lactation. Wounds caused by abscess drainage in cases of caseous lymphadenitis, as well as navel scars were treated by spraying with an antiseptic solution, also containing rosemary-pepper tincture $(20 \%)$.

\section{Conventional management}

In the conventional management (CM) group, estrus synchronization was performed with the use of the hormones PROMONE-E® (Pfizer); PROLISE® (Tecnopec, São Paulo, Brazil); and NOVORMON® (Schering-Plough), according to the protocol suggested by Machado and Simplício (2001). The animals initially received $50 \mathrm{mg}$ of medroxyprogesterone acetate (MPA), impregnated in vaginal sponges, for 11 days. On the $9^{\text {th }}$ day of the treatment, $50 \mathrm{mg}$ of cloprostenol and $300 \mathrm{UI}$ of equine chorionic gonadotropin (eCG) were administered intramuscularly, and, when the goats presented evident behavioral signs of estrus, they were subjected to natural, controlled copulation.

For the treatment against endoparasites, conventional dewormers containing Ivermectin, (IVOMEC INJETÁVEL®; Merial) were initially used depending on the results of the FAMACHAC (Faffa Malan Chart) test. The practice was performed according to the FAMACHA $\odot$ technique (WYK; BATH, 2002), through which the animals to be dewormed were selected based on their infestation level, given by the color categories observed when their ocular mucosa were evaluated. Only the animals presenting mucosa with coloration corresponding to Level 4 or 5 of infestation were treated.

In both types of management (OM and $\mathrm{CM}$ ), we adopted the strategic deworming scheme recommended by Martins et al. (2009), consisting of four doses of anthelminthic medication per year, three in the dry season and one in the humid season. These deworming sessions were performed as follows: the first at the beginning of the dry period, the second circa 60 days later, the third at the end of the dry season, and the fourth in the middle of the humid season, with the respective medications used in each management system, organic or conventional.

For the performance of the milking procedures, the Embrapa Kit for manual milking for dairy goats was used as well, but in this case, iodine-alcohol was used in the post-dipping. Milking was performed manually, twice a day. The strip cup test to detect clinical mastitis was also used during the first three months of lactation.

For the hemogram, $5 \mathrm{~mL}$ of blood was collected from each animal by jugular venipuncture and placed into test tubes with four drops of ethylenediaminetetraacetic acid (EDTA). This procedure was carried out during the lactation period, with one collection in December, three in January, and one in February, for a total of five blood collections. Two hours after the samples arrived in the laboratory, the hemogram was performed using the automated system LAB TEST SD-3VET and the electrical impedance count method to evaluate the red blood cells, hematocrit, mean corpuscular volume, leukocytes, hemoglobin, and mean corpuscular hemoglobin.

The individual feces samples were directly obtained from the rectum every 15 days, starting at 
the beginning of the experiment until its end. The samples were put in labeled plastic bags and kept in coolers without refrigeration until the determination of eggs per gram (EPG) of feces and isolation of larvae (UENO; GONÇALVES, 1998). For helminth egg counting, we used the McMaster technique described by Gordon and Whitlock (1939) and modified by Chagas et al. (2011). The animals were considered infested when more than 100 EPG were found (CHAGAS et al., 2011).

In order to determine the somatic cell count (SCC) and the composition of the milk samples, one sampling was done in December, three in January, and one in February, for a total of 40 samples in each group. The milk production per animal $(\mathrm{kg} /$ animal) was assessed by weighing the milk on a precision scale.

Those milk samples were placed in sterile containers without any preservatives, frozen in a cooler, and sent for laboratorial analyses. The evaluation of the milk composition was carried out using an ultrasonic milk analyzer (EKOMILK TOTAL $\AA$ ), which measured the protein, lactose, fat, and fat-free dry extract. To initiate the analyses, the evaluation was performed three times with random samples of goat milk in order to calibrate the values for the test samples. The first results were discarded, and only the values for the third and subsequent samples were taken into account. Each sample was analyzed in duplicate, with the average value between them taken as the final value.

The SCC was acquired using an electronic somatic cell counter DeLavall (DCC), which stimulates the sample in the cassette with light, increasing its fluorescence signals. These signals are converted into an image that is used to estimate the number of somatic cells in the milk. The cassette is used to collect the milk sample before each count. It contains small amounts of reagents, which, upon being mixed with the milk, react with the nucleus of the somatic cells. The DCC performs the SCC test by reading the milk samples present in the grooves of the cassette needed for the test. After the cassette grooves are filled, it is inserted in the DCC, where, in a matter of seconds, the number of somatic cells/ $\mu l$ is obtained.

The experimental design was entirely randomized with two treatments and 13 replicates. For both the Student's t-test and for the Chisquare test the probability level was set to $5 \%$. All statistical analyses were performed using the statistics software SAS version 9.1.

\section{Results and Discussion}

There was no significant difference $(\mathrm{P}<$ 0.05 ) between the treatments in the percentage of pregnancies. Both in the $\mathrm{OM}$ and in the $\mathrm{CM}$, $61.5 \%$ of the female goats were pregnant. A few female goats in the OM showed behavioral signs of estrus on the same day that the male goats were reintroduced, and others took a little longer, probably due to their individual sexual experience, with the most experienced animals probably being the first to show early behavioral signs and the less experienced responding later to the male stimuli (visual, olfactory, and auditory). However, all goats in this group showed behavioral signs of estrus within 15 days, and were subjected to natural, controlled copulation with the same male.

A few authors (ROSA et al., 2000) observed that the presence of female goats in estrus upon the introduction of the males affects the reproductive activity of the latter and stimulates their response to the other females in estrus. The male courtship results in visual and auditory stimulation so that females that are not in estrus are induced into it, increasing the strength of the stimuli and improving the male effect efficiency (ROSA et al., 2000).

All female goats in the CM showed behavioral signs of estrus on the same day, with only a few hours of variation. A few goats showed the signs in the morning and others in the late afternoon or early evening. The copulation was performed in the same 
way as in the OM. The animals that were first in estrus gave birth at the end of October 2012, and those who showed behavioral signs of estrus later gave birth in November 2012.

In order to increase the efficiency of the male effect, we took into account the sexual experience of the males, since this affects the female response. It is recommended to use sexually experienced males, that is, males at least one year old, for which the characteristic smell and the sexual ardor are more accentuated (SALLES, 2008). The nutrition of the females was carefully considered, since it is known that their weight affects their ovary physiology. Véliz et al. (2006) also reported the importance of the female body weight in the response to the male effect; more than $98.0 \%$ of the females with moderate and high weights showed behavioral signs of estrus 15 days after the male introduction, against only $63.3 \%$ in the group with low body weight $(\mathrm{P}<0.01)$. Santiago-Miramontes et al. (2008) also mentioned the importance of nutritional supplements to the female ovarian response after the males had been introduced.

The absence of reproductive differences between the $\mathrm{OM}$ and the $\mathrm{CM}$ shows that the male effect is a functional, practical, efficient method to induce estrus in female animals. This is very relevant, since the organic management of animal production prohibits the use of synthetic hormones, so the male effect is an alternative to synchronize estrus in dairy goat production, as the group subjected to the use of this natural, low-cost method showed the same outcome as the group that was given high-cost synthetic hormones.

No significant differences were observed between the two types of management in the number of eggs per gram of feces, with similar average values always being observed when the organic and conventional systems were compared (OM: 24 EPG and CM: 35 EPG) (Figure 1).

The organic and conventional groups both had a lower average number of eggs per gram of feces in May and June than in the subsequent months. The values found in both systems were less than 100 eggs per gram of feces, indicating that the animals were not infested. In order to facilitate the understanding of infestation levels, Ueno and Gonçalves (1998) classified a low level infestation as values between 500 and 800 eggs, moderate infestation as values between 800 and 1,500, and high infestation as values above 1,500 eggs, the latter requiring interventions with the administration of anthelminthic medication. However, Molento et al. (2004) and Vieira et al. (2008) claim that animals with EPG counts above 1,500 did not need anthelminthic treatment, since they did not present signs of anemia according to the FAMACHAC method.

In an analysis of the gastrointestinal helminthic dynamics in Saanen goats subjected to organic and conventional production systems during pregnancy, birth, and lactation periods, Silva and Fagundes (2011) observed that the lack of anthelminthic use for animals in the organic system resulted in a moderate level of infestation, showing that organic management offers a viable alternative for the continuous control of helminth levels. In their work with calves, Silva et al. (2012) indicated that infection by gastrointestinal helminthes did not constitute a limiting factor for organic milk production. The nematode levels can be kept moderate through management, even without the use of anthelminthic treatments. 
Figure 1. Number of helminth eggs per gram of feces from goats in the organic and conventional systems between May 2012 and February 2013.

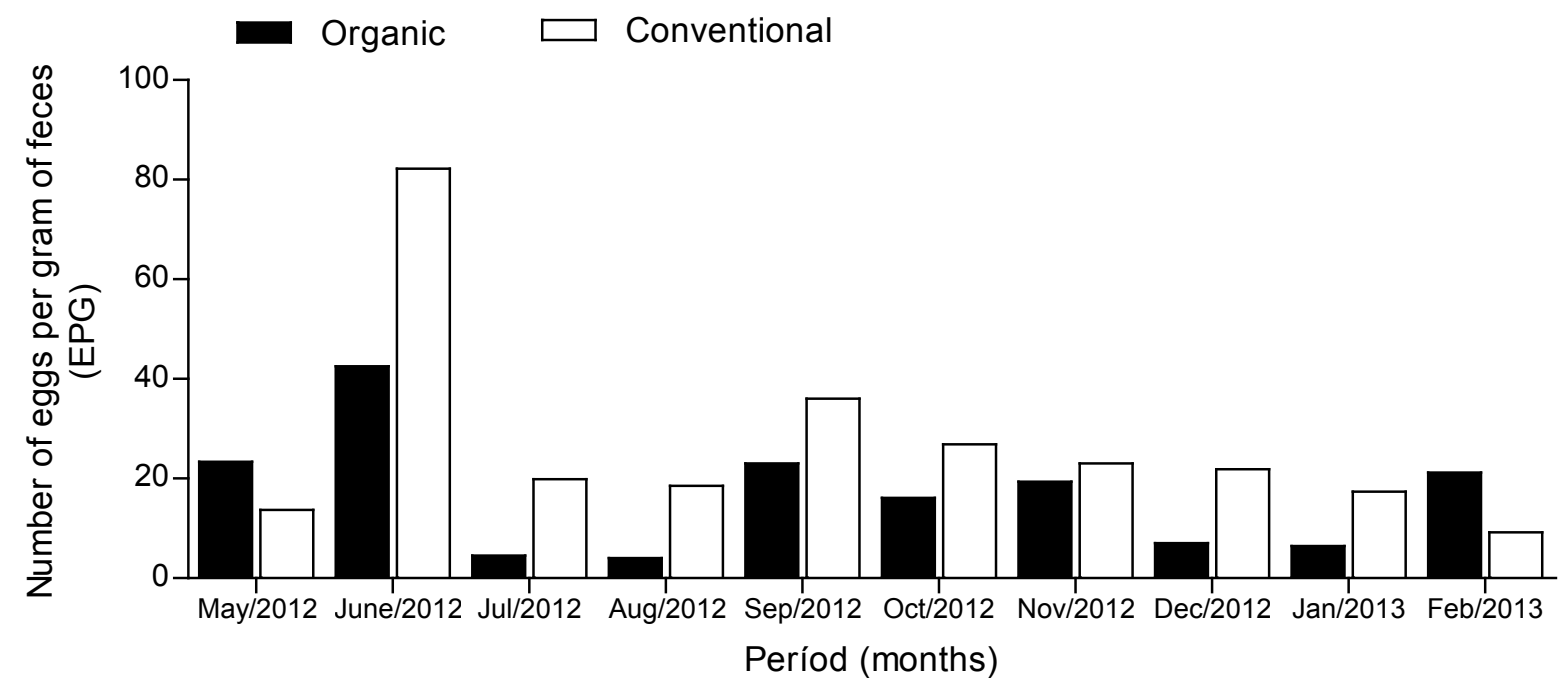

It is believed that the low levels of parasitic infestation observed in the present study are a consequence of the scarce rainfall $(288.2 \mathrm{~mm} /$ year $)$ and moderate temperatures (lowest and highest temperatures of $25^{\circ} \mathrm{C}$ and $33^{\circ} \mathrm{C}$, respectively) in the region of Angicos-RN. The fact that 2012 was one of the driest of recent years in the Northeastern Region contributed to the low infestation of the animals, resulting in the natural control of the parasitic infestation that we observed in this work.

In July 2012, which had low rainfall and slightly higher humidity, there were more eggs per gram of feces (83 and 43 EPG in the organic and conventional groups, respectively) than in the other months, but these values still represented noninfestation. On the other hand, in the months when the temperatures were high and the humidity low, the EPG values decreased, staying within the range considered normal for managed animals, and so, it was not necessary to deworm the animals during the course of the experiment, since they did not show weight loss, the EPG remained low, and no clinical symptoms of parasitic infestation were noted.

According to Martins et al. (2009) and Maia et al. (2009), strategic deworming is required, since in both treatments, with the return of the rainy months (February and March), the animals did not present weight loss and showed controlled EPG values (Figure 1).

A few environmental factors associated with climate, such as temperate, rainfall, humidity, and soil temperature, decisively affect the populations of infesting larvae. Rainfall is a crucial factor in the transmission of most nematodes, as infestation only occurs when the monthly average rainfall is higher than $50 \mathrm{~mm}$ (LEVINE, 1968), an observation corroborated by other epidemiological studies carried out by Embrapa Caprinos e Ovinos in the States of Ceará, Pernambuco, Bahia, Rio Grande do Norte, and Piauí (COSTA; VIEIRA, 1984). A similar situation could have occurred in this study if strategic preventive management had not been used, since in the period before the experiment, in the months of January and February 2012, rainfall values were, respectively, 50 and $190 \mathrm{~mm}$ in the region of Angicos-RN.

The pre-birth period is critical in small ruminant livestock for the occurrence of worm infestations (HELLMEISTER et al., 2003; SILVA; FAGUNDES, 2011) due to the higher susceptibility 
of the animals to parasitic infestations. There was no increase in the EPG, which remained under control both in the animals under OM and those in the CM. The combination of environmental factors and preventive parasite control in both production systems was efficient in the prevention and control of helminthes.

The frequent and massive use of chemical products to control worm infestations does not seems to be the proper way to keep the animals from being infested, as the active compounds are normally modified with the development of worm resistance to the new formulas (SILVA et al., 2013). Living with worms, in a controlled and sustainable way, appears to be the best option. Anthelminthic treatments using active compounds of chemical origin are forbidden in organic dairy production systems, meaning that the prevalence of gastrointestinal nematodes in goats from organic production systems could be higher than that normally found in conventional dairy goats. However, the results of the present work indicate that the animals subjected to OM had lower EPG values when a solution based only on garlic, lemon, and salt was used to prevent infestation.

In this study, a predominance of Levels 2 and 3 was observed, with the organic group having several animals between Levels 1 and 2, which is considered a good result, while the conventional group had many animals at the Levels 2 and 3, and even some at Level 4, which would typically require deworming. However, because the EPG was monitored every 15 days, we opted against deworming, since the animals did not show any symptoms of infestation by gastrointestinal parasites and always had EPG counts below the values for which the use of anthelminthic medication is recommended (Figure 2).
The values observed using the FAMACHAC method corroborated the infestations levels found through EPG counts, demonstrating its efficiency, as well as the possibility of choosing whether or not to deworm. In the OM, score indexes and EPG counts were both lower than the numbers found in the CM (Figure 3). Bath et al. (2001), using the FAMACHAC method, observed a reduction between 38 and $96 \%$, with an average of $58.4 \%$, in the use and costs of drugs when compared to the monthly deworming scheme. In Brazil, using that method for 120 days resulted in a decrease of $79.5 \%$ in the administration of antiparasitic medications to sheep (MOLENTO; DANTAS, 2001).

Frequent individual animal evaluations using the FAMACHAC method help to avoid the occurrence of serious clinical cases of infections and parasitic diseases in the property. Apart from saving on the costs of dewormers, this technique minimizes the problem of residues in products of animal origin and in the environment (MOLENTO et al., 2004). However, it should be used with more precaution when the main parasite present among the herd is Haemonchus contortus, that is, when it represents at least $60 \%$ of the parasites counted from the animals.

No significant variation in the weight of the goats was observed in the course of the experiment (OM $48.53 \mathrm{~kg}$ and CM $55.92 \mathrm{~kg}$ ), a positive fact in any production system, since nutrition is important in strategies to improve the immune response to parasitism. The goats had good body conditions during the whole experiment, with the average weight in the CM being slightly higher than in the $\mathrm{OM}$, even though the values followed the same pattern, without monthly variations within the groups. 
Figure 2. FAMACHAC score frequency in the goats from organic and conventional systems between May 2012 and February 2013.

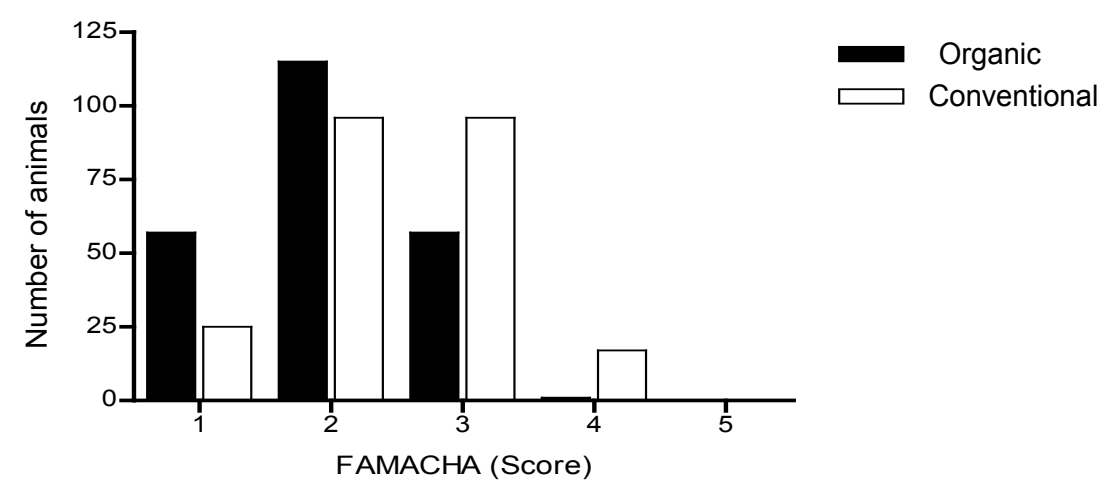

Figure 3. Weight of the goats in the organic and conventional systems between May 2012 and February 2013.

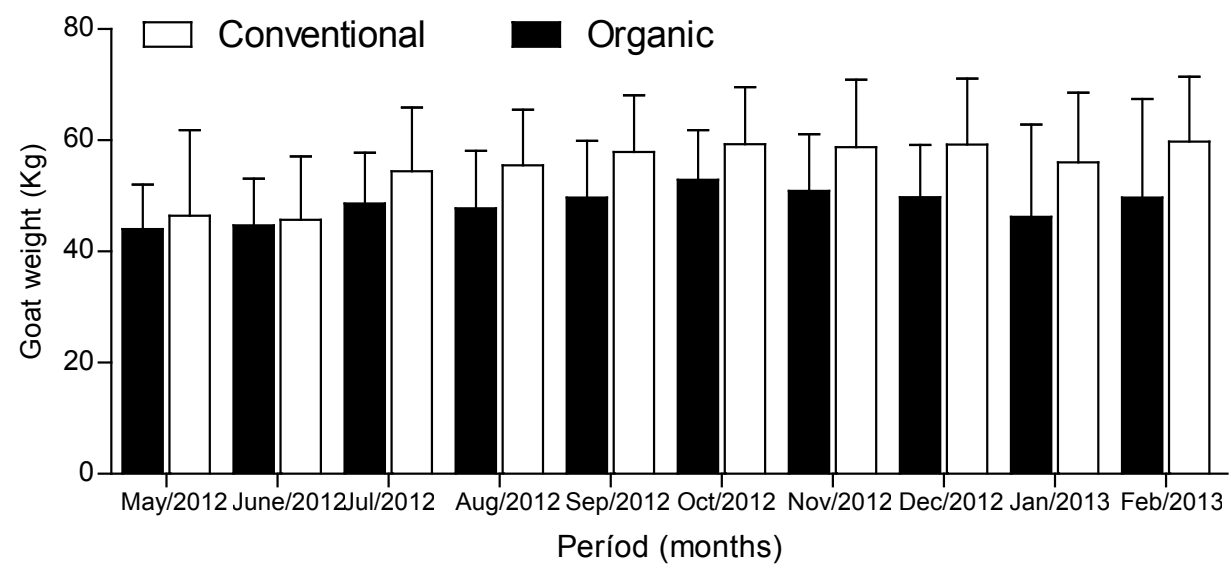

This lack of variation may have been because the diet was poor, basically consisting of material from the caatinga, with few food options for both groups due to the dryness. The low infestation by intestinal worms allowed for better weight gain and the maintenance of the good nutritional state of the animals, which were healthy, free of intestinal worms that affect production, and, consequently, had better nutritional utilization, reflected in the constant weight gain (Figure 3).

According to Sykes and Coop (1976) and Echevarria (1988), the losses caused by the parasite Haemonchus contortus end up affecting productivity indices, such as weight loss, which, according to a few authors, can vary between $20 \%$ and $60 \%$ among sheep. This was not observed in the present study, as the average weight was constant and there was no productivity loss due to the absence of infestations, and the values found in the $\mathrm{OM}$ and in the $\mathrm{CM}$ were not affected by that parasite.

The high pathogenicity of nematodes, particularly Haemonchus contortus, in the small ruminants facilitates the appearance of other diseases and affects the general performance of the herd. This factor, associated with other variables such as race, age, nutrition, and management, may contribute to higher or lower levels of infestation.

At the final stages of pregnancy and during 
lactation, the goats had an accentuated immunity reduction, resulting in an increase in the number and size of parasitic nematodes, and causing severe depletion in their organisms. At this stage, due to the rapid fetal growth, or, later, due to the accentuated utilization of body reserves as a consequence of lactation, there is an increase in the nutritional requirements (2- to 3 -fold the amount required for maintenance), especially in females with higher milk production.

In this study, even after giving birth, the goats did not lose weight (Figure 3), showing that they managed to maintain their average weights without much variation. This may be attributed to the low EPG values before birth, since in this period the females often show weight loss and become more susceptible to infestations by endoparasites. This was not observed in this study, as the animals did not show big weight variations and the EPG values remained low. The lack of infestation before birth contributed to the maintenance of the performance among these animals.

There were no statistically significant differences $(\mathrm{P}<0.05)$ between the management systems in the parameters of milk production and composition
(Table 1). Slightly higher values were observed for milk production in the $\mathrm{OM}(0.97 \mathrm{~kg} /$ day $)$ than the CM $(0.94 \mathrm{~kg} /$ day $)$.

The average values for protein, lactose, total dry extract, and fat-free dry extract were higher in the OM than in the CM $(2.21 ; 2.32 ; 3.30 ; 7.86 ; 5.56$, and $1.81 ; 1.81 ; 2.86 ; 6.74 ; 4.92$, respectively), representing a positive result for the present study. No clinical mastitis was observed using the strip cup test in animals from either of the management systems.

With time, small differences in the milk parameters lead to considerable increases for the producer, since many dairy vendors value not only the product amount but also its quality.

However, the milk parameters were below the values established for goats (BRASIL, 2000). It is believed that, in the dry season in 2012, the large variation in the amount of food, difficulty in acquiring food, and quality of food may have reduced the productivity in both management systems; however, because of the high ability of goats to convert low quality food, they were still able to gain weight and produce milk.

Table 1. Average and standard deviation of milk productivity and composition among goats subjected to organic and conventional managements in the municipality of Angicos-RN.

\begin{tabular}{lccc}
\hline & \multicolumn{2}{c}{ TREATMENTS } & \\
\cline { 2 - 4 } MPb $^{\mathrm{b}}(\mathrm{kg} /$ day) & ORGANIC & CONVENTIONAL & REFERENCE VALUES \\
FAT (\%) & $0.97 \pm 1.00$ & $0.94 \pm 0.86$ & \\
PROTEIN (\%) & $2.21 \pm 0.09$ & $1.81 \pm 0.09$ & MIN 3.0** \\
LACTOSE (\%) & $2.32 \pm 0.08$ & $1.81 \pm 0.09$ & MIN 2.9** \\
FDE (\%) & $3.31 \pm 0.10$ & $2.87 \pm 0.10$ & MIN 2.8** \\
TDE (\%) & $5.66 \pm 0.14$ & $4.93 \pm 0.13$ & MIN 8.2** \\
SCC (SC/mL) & 7.87 & 6.74 & \\
\hline
\end{tabular}

${ }^{\mathrm{b}} \mathrm{MP}=$ milk production, $\mathrm{FDE}=$ fat-free dry extract, $\mathrm{TDE}=$ total dry extract, $\mathrm{SCC}=$ somatic cell count. ** (BRASIL, 2000). 
Even with values below the standards established by goat milk regulations, the OM managed to maintain all the values only slightly below those in the CM. However, the fact that the OM promotes animal well-being makes those results more positive.

Although Brazilian legislation (BRASIL, 2000) does not establish the limits for SCC in goat milk, Table 1 shows that the OM had lower values $(904,860$ $\mathrm{SC} / \mathrm{mL}$ ) using the glycerin solution with rosemarypepper as an antiseptic for the cleaning of milking equipment, with the successful control of bacterial proliferation, as no case of mastitis was observed. In the $\mathrm{CM}$, the value $(1,020,520 \mathrm{SC} / \mathrm{mL})$ was slightly above the limit accepted by the regulations in the United States for type A herds $(1,000,000 \mathrm{SC} / \mathrm{mL})$. It is worth pointing out that no clinical mastitis was observed in any of the animals using the strip cup test in either of the management systems.

SCC is higher in goat milk because of the way the milk is secreted by the mammary gland. In cows, this gland is classified as merocrine, as only the secretion product (milk) is released. In goats, it is classified as apocrine, where the secretion product is released together with small parts of cells, resulting in high SCC (ZENG et al., 1997).

According to Wells and Ott (1998), reasons to monitor the SCC in milk tanks include the demand of the consumer for high quality products, the need to process high quality crude milk, and the pressure of an international market for high quality products. High SCC affects the milk composition (resulting in less fat, protein, and lactose) and the shelf life of its derivatives, leading to great losses for the dairy industry.

All blood sample parameters were within the normal range for goats (Table 2), showing the good health of the animals that were subjected to either organic or conventional treatments.

It is evident that the treatments used in the organic management worked, above all due to the leukocyte counts and to the hematocrit, which showed that there was no infection by bacteria or intestinal worms. Therefore, the use of the organic management system can be justified since it is associated with clean production, which is currently widely accepted. This management system had results within the established standards, without using any allopathic medication for the control of gastrointestinal parasites or mastitis.

According to Ndoutamia and Ganda (2005), clinical hematology is an important parameter of animal health. However, in order to properly interpret hemograms, it is necessary to consider the influence of certain variables: climatic and environmental conditions, nutritional state, pregnancy, lactation, management, race, gender, and age.

Table 2. Average values and standard deviation of blood parameters in the lactation period of goats subjected to the organic and conventional management systems between December 2012 and February 2013.

\begin{tabular}{lccc}
\hline & Organic & Conventional & Reference values (JAIN, 1993) \\
\hline Red blood cells $\left(\times 10^{6} / \mathrm{mL}\right)$ & $14.65 \pm 27.36$ & $13.58 \pm 27.21$ & $8-18$ \\
Hematocrit $(\%)$ & $24.6 \pm 6.66$ & $25.5 \pm 6.15$ & $19-38$ \\
MCV $*(\mathrm{fl})$ & $16.7 \pm 2.83$ & $18.55 \pm 2.94$ & $15-30$ \\
Leukocytes $\left(\times 10^{3} / \mathrm{mL}\right)$ & $9427.50 \pm 4903.97$ & $8658.97 \pm 3115.05$ & $4000-13000$ \\
Hemoglobin $(\mathrm{g} / \mathrm{dL})$ & $9.82 \pm 2.48$ & $9.81 \pm 2.21$ & $8-14$ \\
MCH $* *(\mathrm{pg})$ & $6.67 \pm 0.76$ & $7.28 \pm 0.78$ & $5-7.4$ \\
\hline
\end{tabular}

$* \mathrm{MCV}=$ Median Corpuscular Volume; **MCH = Median Corpuscular Hemoglobin. 
Several studies report a hematocrit increase in animals under heat stress due to their high dependence on evaporative mechanisms as a way of maintaining their homeothermy, leading to a great hydric loss for the environment, with a relative hemoconcentration and increased red blood cell counts (SRIKANDAKUMAR et al., 2004; FERREIRA et al., 2009). When evaluating differences in the eritrogram components in goats, Silva. (2008) observed that native race (e.g., Moxotó) animals of the Northeastern semiarid region had the highest values for red blood cell counts and hematocrit, characteristics that appeared during the adaptation process that took place over years.

\section{Conclusions}

Therefore, we conclude that the organic management was equivalent to the conventional management with regard to weight gain, maintenance of animal health status, reproductive and hygienic controls, and milk quality, and is technically appropriate for dairy goat production systems under semiarid conditions.

\section{Acknowledgments}

We thank CAPES for the financial support and Fazenda Hebron I Farm for providing the animals used in this study.

\section{References}

AROEIRA, L. J. M.; FERNANDES, E. N. Produção orgânica de leite: um desafio atual. Informe Agropecuário, Brasília, v. 22, n. 211, p. 53-57, 2001.

BATH, G. F.; HANSEN, J. W.; KRECER, R. C.; VAN WUK, J. A.;VATTA, A. F. Sustainable approaches for managing haemoncosis in sheep and goats. Cidade: Rome, FAO Animal Production and Health Paper, 2001. $89 \mathrm{p}$.

BRASIL. Ministério da Agricultura. Instrução Normativa $\mathrm{n}^{\circ} 37$ de 31 de outubro de 2000. Regulamento técnico de produção, identidade e qualidade de leite de cabra. Diário Oficial [da] União, Brasília, 8 nov. 2000. Seção 1, p. 23.

. Lei $\mathrm{n}^{\circ}$ 10831, de 23 de dezembro de 2003. Diário Oficial [da] República Federativa do Brasil, Poder Executivo, Brasília, DF, 23 dez. 2003. Seção 1, p. 8.

Política Nacional de Agroecologia e agricultura orgânica. Decreto n ${ }^{\circ}$ 7.794. Diário Oficial [da] República Federativa do Brasil, Poder Executivo, Brasília, DF, 20 ago. 2012. Seção 1. p. 4.

CHAGAS, C. A. C. S.; NICIURA, S. C. M.; MOLENTO, M. B. Manual prático: metodologia de diagnóstico da resistência e de detecção de substâncias ativas em parasitos de ruminantes. Brasília: [s.n.], 2011. 153 p.

CHAPAVAL, L.; MORORÓ, A. M. Kit Embrapa de ordenha manual para caprinos leiteiros. Capril Virtual: Sobral, 2009. Disponível em: <http://www.caprilvirtual. com.br/Artigos/CNPC_Qualidade_Leite.pdf $>$. Acesso em: 22 dez. 2009.

COSTA, C. A. F.; VIEIRA, L. da S. Controle de nematódeos gastrintestinais de caprinos e ovinos do Estado do Ceará - Sobral. Sobral,CE. Embrapa CNPC, 1984. 6 p. (Embrapa/CNPC. Comunicado técnico, 13).

D'ALMEIDA, T. N. Bem-estar animal x segurança alimentar. Higiene Alimentar, Itapetininga, v. 19, n. 132, p. 15-17, 2005.

ECHEVARRIA, F. A. M. Doenças parasitárias de ovinos e seu controle. In: SIMPOSIO PARANAENSE DE OVINOCULTURA, 1988, Guarapuava. Anais... Londrina: IAPAR, 1988. p. 46-47.

FERREIRA, F.; CAMPOS, W. E.; CARVALHO, A. U.; PIRES, M. F. A.; MARTINEZ, M. L.; SILVA, M. V. G. B.; VERNEQUE, R. S.; SILVA, P. F. Parâmetros clínicos, hematológicos, bioquímicos e hormonais de bovinos submetidos ao estresse calórico. Arquivo Brasileiro de Medicina veterinária e Zootecnia, Belo Horizonte, v. 61, n. 4, p. 769-776, 2009.

FIGUEIREDO, E. A. P. de; SOARES, J. P. G. Sistemas orgânicos de produção animal: dimensões técnicas e econômicas. In: REUNIÃO ANUAL DA SOCIEDADE BRASILEIRA DE ZOOTECNIA, 49., 2012, Brasília. Anais... Brasília: SBZ, 2012. 1 CD-ROM.

GORDON, H. M. L; WHITLOCK, A. V. A new technique for counting nematode eggs in sheep feces. Journal Council Scientific Industry Research Australia, Melbourne, v. 12, n. 1, p. 50-52, 1939. 
HELLMEISTER,Z.M.M.;VERÍSSIMO,C.J.;CORTEZ, D. H. Casuística de doenças em um criatório ovino em um período de verão e inverno. In: CONGRESSO DE INICIAÇÃO CIENTIIFICA EM CIÊNCIAS AGRÁRIAS BIOLÓGICAS E AMBIENTAIS, 1., 2003, São Paulo. Anais... São Paulo: Arquivos Instituto Biologia, 2003. CD-ROM.

HÖGLUND, J.; SVENSSON, C.; HESSLE, N. Field survey on the status of internal parasites in calves on organic dairy farms in southwestern Sweden. Veterinary Parasitology, Amsterdam, v. 99, n. 2, p. 113-128, 2001.

INSTITUTO BRASILEIRO DE GEOGRAFIA E ESTATÍSTICA - IBGE. Censo agropecuário. Angicos Rio Grande do Norte, Histórico. Angicos: IBGE, 2013. Disponível em: <http://biblioteca.ibge.gov.br/ visualizacao/dtbs/riograndedonorte/angicos.pdf $>$. Acesso em: 10 ago. 2013

JAIN, N. C. Essentials of veterinary hematology. Philadelphia: Lea and Febiger, 1993. 417 p.

LEVINE, N. D. Nematode parasites of animals and man. Mineapolis: Burgess, 1968. 2734 p.

MACHADO, R.; SIMPLÍCIO, A. A. Avaliação de programas hormonais para a indução e sincronização do estro em caprinos. Pesquisa Agropecuária Brasileira, Brasília, v. 36, n. 1, p. 171-178, 2001.

MAIA, M. S.; REGO, M. M. T.; TORRES, J. F; CONFESSOR JUNIOR, A.; LIMA, C. A. C. Alternativas para a caprinovinocultura na agricultura familiar. Natal: EMPARN, 2009. 36 p. (Circuito de Tecnologias Adaptadas para a Agricultura Familiar, 4).

MARTINS, E. C.; GUIMARÃES, V. P.; VIEIRA, L. S. Controle de verminose nos rebanhos caprino e ovino no semiárido brasileiro: avaliação dos impactos econômicos, sociais e ambientais. Sobral. Embrapa - CNPC, 2009. 13 p. (Embrapa/CNPC. Comunicado técnico, 108).

MOLENTO, M. B.; DANTAS, J. C. Validação do guia FAMACHA para diagnóstico clínico de parasitoses em pequenos ruminantes no Brasil: resultados preliminares. In: ENCONTRO INTERNACIONAL SOBRE AGROECOLOGIA E DESENVOLVIMENTO RURAL SUSTENTÁVEL, 1., 2001, Botucatu. Anais... Botucatu: Faculdade de Ciências Agronômicas/UNESP, 2001. v. 1, p. 51.

MOLENTO, M. B.; TASCA, C.; GALLO, A.; FERREIRA, M.; BONONI, R.; STECCA, E. Método Famacha como parâmetro clínico individual de infecção por Haemonchus contortus em pequenos ruminantes. Ciência Rural, Santa Maria, v. 34, n. 4, p. 1139-1145, 2004.
NDOUTAMIA, G.; GANDA, K. Determination des paramétres hematologiques et biochemiques des petits ruminants du Tchad. Revie Médecine Veterinaire, Toulouse, v. 156, n. 4, p. 202-206, 2005.

ROSA, H. J. D.; JUNIPER, D. T.; BRYANT, M. J. Effects of recent sexual experience and melatonin treatment of rams on plasma testosterone concentration, sexual behaviour and ability to induce ovulation in seasonally anoestrous ewes. Journal of Reproduction and Fertility, v. 120, n. 1, p. 169-176, 2000.

SALLES, H. O. Efeito macho: alternativa natural de sincronização de estro para a produção orgânica de caprinos e ovinos. Sobral: Embrapa-CNPC, 2008. 5 p. (Embrapa/CNPC, Comunicado técnico, 92).

SANTIAGO-MIRAMONTES, M. A. de; RIVASMUÑOZ, R.; MUÑOZ-GUTIÉRREZ, M.; MALPAUX, B.; SCARAMUZZI, R. J.; DELGADILlO, J. A. The ovulation rate in anoestrous female goats managed under grazing conditions and exposed to the male effect is increased by nutritional supplementation. Animal of Reproduction Science, Melbourne, v. 105, n. 3-4, p. 409416, 2008.

SILVA, J. B.; FAGUNDES, G. M. Dynamics of gastrointestinal parasitoses in goats kept in organic and conventional production systems in Brazil. Small Ruminant Reseach, Thessaloníki, v. 98, n. 1-3, p. 35-38, 2011

SILVA, J. B.; SOARES, J. P. G.; FONSECA, A. H. Avaliação da carga parasitária de helmintos e protozoários em bezerros manejados em sistema orgânico. Semina: Ciências Agrárias, Londrina, v. 33, n. 3, p. 1103-1112, 2012.

SILVA, J. B.; FAGUNDES, G. M.; SOARES, J. P. G; FONSECA, A. F. Dairy goat health management and milk production on organic and conventional system in Brazil. Semina: Ciências Agrárias, Londrina, v. 34, n. 3, p. 1273-1280, maio/jun. 2013.

SILVA, R. G. Biofisica ambiental: os animais e seu ambiente. São Paulo: FUNEP, 2008. 450 p.

SOARES, J. P. G.; NOGUEIRA, D. M.; DIAS, J.; FONSECA, C. E. M. Orientações técnicas para produção de leite de cabra em sistema orgânico. Petrolina: EMBRAPA Semiárido, 2010. v. 100, 96 p.

SOARES, J. P. G.; AROEIRA, L. J. M.; FONSECA, A. H. F.; FAGUNDES, G. M.; SILVA, J. B. Produção orgânica de leite: desafios e perspectivas. In: SIMPÓSIO NACIONAL DE BOVINOCULTURA 
LEITEIRA, SIMPÓSIO INTERNACIONAL DE BOVINOCULTURA LEITEIRA, 3; 1., 2011, Viçosa. Anais... Viçosa: Suprema Gráfica e Editora, 2011. v. 1, p. 13-43.

SRIKANDAKUMAR, A.; JHONSON, E. H.; MAHGOUB, O. Effect of heat stress on respiratory rate, rectal temperature and blood chemistry in Omani and Australian Merino sheep. Small Ruminant Research, Thessaloníki, v. 49, n.2, p. 193-198, 2004.

SYKES, A. R.; COOP, R. L. Intake and utilisation of food by growing lambs with parasitic damage in the small intestine caused by daily dosing with Trichostrongylus colubriformis larvae. Journal of Agriculture Science, Cambridge, v. 86, n. 3, p. 507-515, 1976.

UENO, H.; GONÇALVES, P. C. Manual para diagnóstico de helmintoses de ruminantes. 4. ed. Tokyo: Japan International Cooperation Ageny (JICA), 1998. $143 \mathrm{p}$.

VÉLIZ, F. G.; POINDRON, P.; MALPAUX, B.; DELGADILlO, J. A. Positive correlation between the body weight of anestrous goats and their response to the male effect with sexually active bucks. Reproduction, Nutrition and Development, Abeerden, v. 46, n. 6, p. 657661, 2006.

VIEIRA, L. S. Métodos alternativos de controle de nematóides gastrintestinais em caprinos e ovinos. Revista Tecnologia e Ciência Agropecuária, v. 2, n. 2, p. 28-31, 2008.

WYK, J. A. V.; BATH, G. F. The FAMACHA system for managing haemoncosis in sheep and goats by clinically identifying individual animals for treatment. Veterinary Research, London, v. 33, n. 5, p. 509-529, 2002.

WELLS, S. J.; OTT, S. L. What is the current milk quality in the US? In: NATIONAL MASTITIS COUNCIL ANNUAL MEETING, 37., 1998, St. Louis. Proceedings... Madison: National Mastitis Council, 1998. p. 10-18.

ZENG, S. S.; ESCOBAR, E. N.; POPHAM, T. Daily variations in somatic cell count, composition and production of Alpine goat milk. Small Ruminant Research, Thessaloniki, v. 26, n. 3, p. 253-260, 1997. 